\title{
EDITORIAL
}

\section{In This Issue: Through the Lens of a Clinician}

\author{
Louise S. Acheson, MD, MS, Associate Editor \\ Department of Family Medicine and Community Health, Case Western Reserve University, Cleveland, Ohio
}

Ann Fam Med 2012;10:490-491. doi:10.1370/afm.1456

\section{PRIMARY CARE WORKFORCE EXPANSION}

I

$\mathrm{n}$ this issue, an analysis of the primary care work-

force predicts that the United States will need

52,000 more primary care physicians by $2025 .{ }^{1}$

Population growth will be the single, most important driver, 10 -fold more than expansion of insurance coverage-but insurance expansion will occur soonest and most abruptly. The new estimate recognizes that not all primary care physicians practice full time in the office; it is based on the current average across all primary care physicians of 48 office visits with patients per week (rather than 76 visits per week for a physician in full-time office practice).

\section{CLINICALLY RELEVANT RESEARCH}

As a family physician, I am fascinated by the variety of clinically relevant articles in this issue. Because almost all of this research was conducted-and much of it generated-in primary care, it can directly help us to understand and improve what we do.

- The systematic review and meta-analysis by Johnson et al compares more- and less-effective ways to increase influenza and pneumococcal immunization rates, which are currently below national targets. ${ }^{2}$

- A 12-country study reveals the prevalence of undiagnosed asthma or chronic obstructive pulmonary disease in unselected patients with acute cough. ${ }^{3}$

- A companion article shows a low yield of actionable incidental findings on chest radiographs of patients with acute cough in primary care. ${ }^{4}$

- Systematically asking women's pregnancy intentions and contraceptive method as a vital sign increases documentation. ${ }^{5}$ One goal is to prevent prescribing of teratogenic medications (eg, statins, angiotensin-converting enzyme inhibi- tors) to fertile women. Including men in this vital sign might further enhance the vital preventive effort to implement effective contraception for everyone who wants or needs it.

- Karaca describes a method for treating ingrown toenails that prevents recurrences. ${ }^{6}$ The Annals editors thought that, were we to adopt this procedure, we would probably substitute local anesthetic without a vasoconstrictor, recognizing that it is common practice in the United States not to use epinephrine in digital blocks.

- A placebo-controlled trial among vitamin D-deficient people found vitamin D helpful for nonspecific muscular aches and pains. ${ }^{7}$ Does this agree with your clinical experience?

- A birthing center located in a rural family practice serving Amish women offers childbirth care tailored to the community-and "an opportunity to look at the effects of local culture and practices that support vaginal birth and [successful] TOLAC [trial of birth after cesarean]."8

These studies range from case series to randomized controlled trials, with many different research techniques. To further develop research capacity, Peterson et $\mathrm{al}^{9}$ report that they have defined research architecture, processes, and requirements of software to support community practice-based translational research: eg, recruitment of participants, collection of aggregated anonymous data, and retrieval of identifiable data from previously consented adults across hundreds of practices.

\section{PREVENTION 'NUMERACY'}

In this issue you will find a research study, ${ }^{10}$ an essay, ${ }^{11}$ and a guest editorial ${ }^{12}$ on screening. In their essay Hoffman and colleagues caution guideline makers to "avoid distracting primary care clinicians from providing services with proven benefit and value for 
patients."11 Indeed, many preventive interventions have proven benefit. Yet Hudson et al present the quandary that many patients appear willing to undergo preventive care on the basis of "overly optimistic expectations of the benefits of preventive interventions and screening."10 Are they innumerate or overly optimistic? What about policy makers? What about clinicians?

We hope you will share your thoughts about the articles in this issue. Join the discussion at http://www. AnnFamMed.org.

\section{References \\ 1. Petterson SM, Liaw WR, Phillips RL Jr, Rabin DL, Meyers DS, Baze- more AW. Projecting US primary care physician workforce needs: 2010-2025. Ann Fam Med. 2012;10(6):503-509. \\ 2. Lau D, Hu J, Majumdar SR, Storie DA, Rees SE, Johnson JA. Inter- ventions to improve influenza and pneumococcal vaccination rates among community-dwelling adults: a systematic review and meta- analysis. Ann Fam Med. 2012;10(6):538-546 \\ 3. van Vugt S, Broekhuizen L, Zuithoff N, et al. Airway obstruction and bronchodilator responsiveness in adults with acute cough. Ann Fam Med. 2012;10(6):523-529. \\ 4. van Vugt S, Broekhuizen L, Zuithoff $N$, et al. Incidental chest radio- graphic findings in adult patients with acute cough. Ann Fam Med. 2012;10(6):510-515.}

5. Schwarz EB, Parisi SM, Williams SL, Shevchik GJ, Hess R. Promoting safe prescribing in primary care with a contraceptive vital sign: a cluster-randomized controlled trial. Ann Fam Med. 2012;10(6):516-522.

6. Karaca N, Dereli T. Treatment of ingrown toenail with proximolateral matrix partial excision and matrix phenolization. Ann Fam Med. 2012;10(6):556-559.

7. Schreuder F, Bernsen RMD, van der Wouden JC. Vitamin D supplementation for nonspecific musculoskeletal pain in non-Western immigrants: a randomized controlled trial. Ann Fam Med. 2012; 10(6):547-555.

8. Deline J, Varnes-Epstein L, Dresang LT, Gideonsen M, Lynch L, Frey JJ III. Low primary cesarean rate and high VBAC rate with good outcomes in an Amish birthing center. Ann Fam Med. 2012;10(6): 530-537.

9. Peterson KA, Delaney BC, Arvanitis T, et al. A model for the electronic support of practice-based research networks. Ann Fam Med. 2012;10(6):560-567.

10. Hudson B, Zarifeh A, Young L, Wells JE. Patients' expectations of screening and preventive treatments. Ann Fam Med. 2012;10(6): 495-502.

11. Hoffman RM, Barry MJ, Roberts RG, Sox HC. Reconciling primary care and specialist perspectives on prostate cancer screening. Ann Fam Med. 2012;10(6):568-571.

12. Woolf SH. The price of false beliefs: unrealistic expectations as a contributor to the health care crisis. Ann Fam Med. 2012;10(6): 491-494.

\section{EDITORIAL}

\section{The Price of False Beliefs: Unrealistic Expectations as a Contributor to the Health Care Crisis}

Steven H. Woolf, MD, MPH

Department of Family Medicine, School of Medicine, Virginia Commonwealth University, Richmond, Virginia

Ann Fam Med 2012;10:491-494. doi:10.1370/afm.1452.

$\mathrm{T}$ he alarming rise in health care costs haunts our society. The United States now spends $\$ 2.6$ trillion per year on health care, ${ }^{1}$ and the spiral-

ing costs are placing unsustainable burdens on employers and workers, Medicare and Medicaid, state and local governments, and American families. A growing proportion of Americans are now foregoing health care to pay for other household needs or are facing bankruptcy. ${ }^{2} \mathrm{~A}$ variety of strategies have been proposed to slow medical cost inflation, such as realigning financial incentives to discourage costly procedures, account-
Conflicts of interest: none reported.

\section{CORRESPONDING ADDRESS}

Steven H. Woolf, MD, MPH

Department of Family Medicine

School of Medicine

Virginia Commonwealth University

1200 East Broad St

PO Box 980251

Richmond, VA 23298-0251

swoolf@vcu.edu 